\title{
COMPARISON OF TIMBAL LEVELS (Pb) ON BLOOD SHELLS (Anadara granosa) AND BAKAU (Shell Telescopium telescopium) IN PLACE AUCTION OF FISH (TPI) LAPPA SINJAI DISTRICT
}

\section{PERBANDINGAN KADAR TIMBAL (Pb) PADA KERANG DARAH (Anadara granosa) DAN KERANG BAKAU (Telescopium telescopium) DI TEMPAT PELELANGAN IKAN (TPI) LAPPA KABUPATEN SINJAI}

\author{
Rahmawati, Wa Ode Rustiah, Nurhidayat, Novie Rezkiyana Dewi M. \\ Politeknik Kesehatan Muhammadiyah Makassar \\ *Email korespondensi: wati r77@yahoo.com \\ rahmawatiamma60@gmail.com
}

\begin{abstract}
Shellfish is one of the sea products that is very popular with the community including the community in Sinjai Regency as a potential coastal and fishery resources that have a fish auction place (TPI). Shellfish are one of the most efficient marine animals to accumulate heavy metals. This is due to the fact that shellfish live in the bottom sedimentary layer of water, move very slowly, and their food comes from detritus in the bottom waters, so the chance of entering heavy metals into the body is very large. Shells can be contaminated by lead $(\mathrm{Pb})$ which enters the body of water through the crystallization of lead in the air with the help of rain water. Lead which accumulates in water and sediments will enter the water and accumulate in the water causing toxic effects on the organisms in it, including some types of shellfish. If humans consume shells that contain heavy metals in high enough quantities will have a negative impact on health. In the human body, heavy metals will combine with active enzymes to become inactive enzymes, so the synthesis of red blood grains $(\mathrm{Hb})$ can be inhibited, consequently it can cause anemia. The purpose of the study was to determine lead content $(\mathrm{Pb})$ in the sample of shellfish. The object of research is blood shells and mangrove shells, analyzed using the Atomic Absorption Spectrophotometer (SSA) method with a total sample of 10 . The results obtained by lead $(\mathrm{Pb}$ ) in blood shells (Anadara granosa) with an average of $0.0439 \mathrm{mg} / \mathrm{kg}$ while the mangrove shells (Telescopium telescopium) with an average of $0.0176 \mathrm{mg} / \mathrm{kg}$. Both shellfish samples did not exceed the maximum limit set by the Indonesian National Standard (SNI) of $1.5 \mathrm{mg} / \mathrm{kg}$. Based on the data analysis test $p$ value $=0.011<0.05$ which can be concluded that there is a significant difference between the levels of lead $(\mathrm{Pb})$ in blood shells (Anadara granosa) and mangrove shells (Telescopium telescopium).
\end{abstract}

Keywords: Blood Shells (Anadara granosa), Mangrove Shells (Telescopium telescopium), Lead (Pb), Atomic Absorption Spectrophotometer (SSA)

\section{ABSTRAK}

Kerang merupakan salah satu hasil laut yang sangat digemari oleh masyarakat termasuk masyarakat di Kabupaten Sinjai sebagai potensi sumber daya pesisir laut dan perikanan yang memiliki tempat pelelangan ikan (TPI). Salah satu hewan laut yang paling efisien mengakumulasi logam berat. Hal ini disebabkan, karena kerang hidup di lapisan sedimen dasar perairan, bergerak sangat lambat, dan makanannya berasal dari detritus di dasar perairan, sehingga peluang masuk logam berat ke dalam tubuh sangat besar. Kerang dapat tercemar oleh timbal (Pb) yang masuk ke badan perairan melalui pengkristalan timbal diudara dengan bantuan air hujan. Timbal yang menumpuk pada air dan sedimen akan masuk ke dalam perairan dan terakumulasi k edalam air sehingga menimbulkan efek toksik terhadap organisme di dalamnya termasuk ke beberapa jenis kerang. Apabila manusia mengkonsumsi kerang yang mengandung logam berat dalam jumlah yang cukup tinggi akan berdampak negatif terhadap kesehatan. Dalam tubuh manusia, logam berat akan bersenyawa dengan enzim aktif menjadi enzim tidak aktif, sehingga sintesis butir darah merah $(\mathrm{Hb})$ dapat dihambat, akibatnya dapat menimbulkan penyakit anemia. Tujuan penelitian untuk menentukan kadar timbal $(\mathrm{Pb})$ pada sampel kerang. Objek penelitian yaitu kerang darah dan kerang bakau, dianalisis dengan menggunakan metode Spektrofotometer Serapan Atom (SSA) dengan jumlah sampel sebanyak 10. Hasil penelitian diperoleh kadar timbal (Pb) pada kerang darah (Anadara granosa) dengan rata-rata $0,0439 \mathrm{mg} / \mathrm{kg}$ sedangkan pada kerang bakau (Telescopium telescopium) dengan rata-rata $0,0176 \mathrm{mg} / \mathrm{kg}$. Kedua sampel kerang tidak melebihi batas maksimum yang ditetapkan Standar Nasional Indonesia (SNI) sebesar $1,5 \mathrm{mg} / \mathrm{kg}$. Berdasarkan uji analisis data diperoleh nilai $p=0.011<0.05$ yang dapat disimpulkan bahwa terdapat perbedaan yang signifikan antara kadar timbal $(\mathrm{Pb})$ pada kerang darah (Anadara granosa) dan kerang bakau (Telescopium telescopium).

Kata Kunci: Kerang Darah (Anadara granosa), Kerang Bakau (Telescopium telescopium), Timbal (Pb), Spektrofotometer Serapan Atom (SSA) 


\section{PENDAHULUAN}

Indonesia merupakan suatu negara dengan luas perairan lebih besar dari pada luas daratan, maka dari itu Indonesia disebut sebagai negara maritim. Indonesia juga memiliki berbagai macam pulau dan provinsi. Salah satunya yaitu Provinsi Sulawesi Selatan yang memiliki banyak sektor yang bisa berpotensi sebagai sumber perekonomian dan pembangunan secara menyeluruh. Beberapa potensi yang berkembang didaerah ini meliputi, ekonomi, perairan, perkebunan, pariwisata dan perikanan. Dalam hal ini, Provinsi Sulawesi Selatan memiliki suatu daerah yaitu Kabupaten Sinjai yang dijadikan sebagai tolak ukur dalam peningkatan jumlah hasil tangkapan, karena letak daerahnya memiliki pantai dengan potensi perikanan yang cukup besar (Setiawan, 2013).

Jika ditinjau dari segi geografis Kabupaten Sinjai adalah salah satu Kabupaten yang sangat berpotensi dari aspek kelautan dan perikanan. Potensi perikanan di Kabupaten Sinjai terdiri dari perikanan tangkap (perikanan laut) dan perikanan budidaya (perikanan darat). Munculnya Tempat Pelelangan Ikan (TPI) di Kabupaten Sinjai menyebabkan ramainya aktivitas kenelayanan, baik aktivitas penangkapan ikan dan aktivitas pemasaran ikan. Tempat Pelelangan Ikan ini ditetapkan sebagai tempat untuk penjualan ikan produksi nelayan Kabupaten Sinjai.

Potensi sumber daya pesisir dan laut terutama sumber hayati ikan, kerang, dan sejenisnya telah dieksploitasi secara berlebihan. Sumber daya pesisir tersebut merupakan unsur-unsur hayati dan nonhayati yang terdapat diwilayah laut, terdiri atas unsur hayati berupa ikan, kerangkerangan, terumbu karang, dan biota lain beserta ekosistemnya (Syah, 2017).

Kerang adalah organisme yang hidup dengan cara menyaring makanan (filter feeder) terhadap material yang tersuspensi diperairan atau sedimen. Pemanfataan kerang sebagai sumber bahan makanan cukup banyak digemari oleh masyarakat yang hidup disekitar pesisir pantai. Jenis kerang yang sering menjadi konsumsi masyarakat di Kabupaten Sinjai yaitu kerang darah (Anadara granosa) dan kerang bakau (Telescopium telescopium) (Emawati et al., 2015).

Kerang darah ini sangat bergantung pada jenis plankton atau partikel-partikel bahan organik sebagai sumber makanannya
(Melinda et al., 2015). Kerang merupakan salah satu hewan laut yang paling efisien mengakumulasi logam berat. $\mathrm{Hal}$ ini disebabkan, kerang hidup di lapisan sedimen dasar perairan, bergerak sangat lambat, dan makanannya adalah detritus di dasar perairan, sehingga peluang masuk logam berat ke dalam tubuh sangat besar (Rachmawati dan Ma'ruf, 2013).

Salah satu unsur logam berat yang dapat mengakibatkan keracunan pada makhluk hidup adalah timbal $(\mathrm{Pb})$. Timbal dapat berada di dalam badan perairan secara alamiah dan sebagai dampak dari aktifitas manusia, diantaranya adalah bahan bakar bensin yang beradiktif dan bengkel otomotif yang terdapat disekitar aliran sungai. Secara alamiah, timbal dapat masuk ke badan perairan melalui pengkristalan timbal di udara dengan bantuan air hujan. Timbal yang menumpuk pada air dan sedimen akan masuk ke dalam perairan dan kemudian terakumulasi ke dalam air, biota, serta sedimen pada perairan tersebut sehingga menimbulkan efek toksik terhadap organisme di dalamnya termasuk ke beberapa jenis kerang (Ramadhan et al., 2017).

Logam berat $\mathrm{Pb}$ yang berasal dari segala aktivitas manusia (terutama aktifitas pelabuhan) akan masuk ke dalam perairan turun dan mengendap pada dasar perairan kemudian akan terakumulasi ke dalam sedimen, dan hal ini akan menyebabkan organisme yang mencari makan di dasar perairan seperti udang, rajungan, dan kerang akan memiliki peluang yang besar untuk terpapar logam berat yang telah terikat di dasar perairan dan membentuk sedimen. Penelitian Amin, dkk (2011) menyatakan bahwa sumber pencemar $\mathrm{Pb}$ masuk ke perairan diperkirakan kebanyakan berasal dari aktivitas kapal-kapal nelayan, kapalkapal penyebrangan dan bahan pencemar yang terbawa oleh arus.

Apabila manusia mengkonsumsi kerang yang mengandung logam berat dalam jumlah yang cukup tinggi akan berdampak negatif terhadap kesehatan. Beberapa logam berat yang umum ditemukan dalam kerang adalah timbal, kadmium, tembaga dan seng. Dalam tubuh manusia, logam berat akan bersenyawa dengan enzim aktif menjadi enzim tidak aktif, sehingga sintesis butir darah merah $(\mathrm{Hb})$ dapat dihambat, akibatnya dapat menimbulkan penyakit anemia. Kerang merupakan biota yang berpotensi 
terkontaminasi logam berat karena hidupnya didalam sedimen (lumpur) (Apriyanti, 2018).

Penelitian yang telah dilakukan oleh Naimin (2014) dengan judul penelitan "Analisis kadar timbal $(\mathrm{Pb})$ pada kerang darah (Anadara granosa) di perairan teluk bone (Kab. Sinjai) dengan menggunakan metode Spektrofotometer Serapan Atom" mendapatkan hasil bahwa logam timbal $(\mathrm{Pb})$ dalam kerang darah (Anadara granosa) sampel I sebesar $0,0739 \mathrm{mg} / \mathrm{kg}$ dan sampel II sebesar $0.0267 \mathrm{mg} / \mathrm{kg}$, tidak melebihi batas maksimum menurut SNI (Standar Nasional Indonesia) tahun 2009 yaitu 1,5 $\mathrm{mg} / \mathrm{kg}$.

Dampak logam berat $\mathrm{Pb}$ sangat berbahaya bagi kesehatan manusia yang mengkonsumsi, sehingga penting untuk mengetahui kadar logam berat $\mathrm{Pb}$ yang ada di dalam kerang darah dan kerang bakau. Oleh karena itu, tujuan dari penelitian ini adalah untuk menentukan kadar timbal $(\mathrm{Pb})$ yang terkandung di dalam Kerang Darah (Anadara granosa) dan Kerang Bakau (Telescopium telescopium) di TPI Lappa Kabupaten Sinjai serta untuk mengetahui perbedaan yang signifikan antara kadar timbal $(\mathrm{Pb})$ yang terkandung di dalam Kerang Darah (Anadara granosa) dan Kerang Bakau (Telescopium telescopium) di TPI Lappa Kabupaten Sinjai.

\section{METODE PENELITIAN Jenis Penelitian}

Penelitian ini adalah jenis penelitian komparatif yaitu untuk perbandingan kadar timbal $(\mathrm{Pb})$ pada Kerang Darah (Anadara granosa) Dan Kerang Bakau (Telescopium telescopium) yang terdapat di tempat pelelangan ikan (TPI) Lappa Kab. Sinjai

\section{Lokasi dan Waktu Penelitian}

Lokasi pengambilan sampel di tempat pelelangan ikan (TPI) Lappa Kabupaten Sinjai, dan lokasi penelitian dilaksanakan di Balai Besar Laboratorium Kesehatan (BBLK) Makassar, serta waktu penelitian dilaksanakan pada tanggal 2 - 10 Mei 2019.

\section{Populasi dan Sampel}

Populasi pada penelitian ini adalah semua jenis kerang darah (Anadara granosa) dan jenis kerang bakau (Telescopium telescopium) yang terdapat di TPI Lappa Kab. Sinjai. Sampel dalam penelitian ini adalah sebanyak 5 sampel Kerang Darah (Anadara granosa) dan 5 sampel Kerang Bakau (Telescopium telescopium) yang terdapat di tempat pelelangan ikan (TPI) Lappa Kab. Sinjai.

\section{Teknik Pengambilan Sampel}

Teknik pengambilan sampel pada penelitian ini adalah dengan menggunakan Random Sampling yaitu dengan mengambil sampel yang didapatkan secara acak saat pengambilan sampel.

\section{Alat dan Bahan}

Alat yang dipakai pada penelitian ini adalah gelas ukur $25 \mathrm{~mL}$, pipet ukur $1 \mathrm{~mL} ; 5$ $\mathrm{mL} ; 10 \mathrm{~mL} ; 15 \mathrm{~mL}$, dan $20 \mathrm{~mL}$, corong gelas, cawan porselin, cawan petri, botol gelas, pemanas listrik, kertas saring, labu semprot, timbangan, tanur, Spektrofotometer Serapan Atom.

Bahan yang dipakai pada penelitian ini adalah air suling, larutan standar logam timbal $(\mathrm{Pb})$, larutan asam nitrat $\left(\mathrm{HNO}_{3}\right)$ pekat, gas asetilen $\left(\mathrm{C}_{2} \mathrm{H}_{2}\right)$. kerang darah (Anadara granosa) dan kerang Bakau (Telescopium telescopium)

\section{Prosedur Kerja}

1) Pengambilan Sampel

Sampel kerang darah (Anadara
granosa) dan kerang bakau
(Telescopium telescopium) yang diambil
di TPI Lappa Kabupaten Sinjai
Persiapan Sampel

2) Persiapan Sampel

Cangkang kerang dibuka dengan menggunakan pisau dan dikeluarkan isinya, setelah itu dicuci kemudian dibersihkan dengan air mengalir. Ditimbang seksama 5 gram daging kerang darah (Anadara granosa) dan kerang bakau (Telescopium telescopium) dalam cawan porselin, lalu dipanaskan dalam tanur pada suhu $600^{\circ} \mathrm{C}$ sampai diperoleh abu yang berwarna keputih-putihan. Setelah itu ditambahkan 0,5 $\mathrm{ml}\left(\mathrm{HNO}_{3}\right)$ pekat, lalu dipanaskan di atas penangas air sampai kering kemudian dimasukkan kembali ke dalam tanur selama setengah jam dan didinginkan kemudian ditambahkan $0,5 \mathrm{ml}\left(\mathrm{HNO}_{3}\right)$ pekat dan dimasukkan ke dalam gelas ukur $25 \mathrm{ml}$, dicukupkan volumenya dengan air suling hingga batas tanda kemudian disaring, setelah itu diukur dengan SSA.

3) Pembuatan larutan baku kerja timbal $(\mathrm{Pb})$

a. Larutan induk timbal $1000 \mathrm{ppm}$, dilarutkan 1,5985 gram $\mathrm{Pb}\left(\mathrm{NO}_{3}\right)_{2}$ dalam $500 \mathrm{ml}$ aquades, kemudian 
dimasukkan ke dalam labu ukur $1000 \mathrm{ml}$ dan diencerkan sampai tanda batas.

b. Larutan baku kerja Pb 100 ppm, dibuat dengan mengambil sebanyak $10 \mathrm{~mL}$ larutan baku induk 1000 ppm, kemudian diencerkan dalam labu ukur $100 \mathrm{~mL}$ dengan aquades hingga volumenya $100 \mathrm{~mL}$

c. Larutan baku kerja $\mathrm{Pb} 10$ ppm, dibuat dengan mengambil sebanyak $10 \mathrm{~mL}$ larutan baku kerja 100 ppm, kemudian diencerkan dalam labu ukur $100 \mathrm{~mL}$ dengan aquades hingga tepat volumenya.

d. Deret larutan baku kerja $\mathrm{Pb}$, diambil masing-masing sebanyak 5, 10, 20, 30 , dan $40 \mathrm{~mL}$ larutan baku kerja 10 ppm, kemudian diencerkan dalam labu ukur $100 \mathrm{~mL}$ dengan aquades hingga tepat volumenya untuk memperoleh konsentrasi 0,$5 ; 1 ; 2 ; 3$ dan 4 ppm.

\section{Interpretasi Hasil}

Data di peroleh dari hasil pengukuran kadar logam $\mathrm{Pb}$ dalam daging kerang darah (Anadara granosa) dan daging kerang bakau (Telescopium telescopium) dengan menggunakan Spektrofotometer Serapan Atom. Berdasarkan Standar Nasional Indonesia (SNI) tahun 2009 batas maksimum timbal pada kerang $1,5 \mathrm{mg} / \mathrm{kg}$.

\section{Analisis Data}

Data yang diperoleh akan disajikan dalam bentuk tabel kemudian dinarasikan secara deskriptif. Data yang diperoleh dianalisa dengan menggunakan rumus uji statistic SPSS (Uji T dua sampel bebas) (Stang, 2014).

\section{HASIL}

Berdasarkan hasil penelitian "Perbandingan Kadar Timbal (Pb) Pada Kerang Darah (Anadara granosa) dan Kerang Bakau (Telescopium telescopium) Di Tempat Pelelangan Ikan (TPI) Lappa Kabupaten Sinjai" yang dilakukan pada tanggal 2 - 10 Mei 2019 di Balai Besar Laboratorium Kesehatan Makassar, sebanyak 10 sampel secara random sampling di peroleh hasil yang dapat dilihat padaTabel 3.

Dari hasil penelitian diperoleh kadar Timbal ( $\mathrm{Pb}$ ) pada sampel 1 (kerang darah) sebanyak 0,0500 mg/kg, sampel 2 (kerang darah) sebanyak $0,0185 \mathrm{mg} / \mathrm{kg}$, sampel 3 (kerang darah) sebanyak $0,363 \mathrm{mg} / \mathrm{kg}$, sampel 4 (kerang darah) sebanyak 0,0493 $\mathrm{mg} / \mathrm{kg}$, sampel 5 (kerang darah) sebanyak $0,0654 \mathrm{mg} / \mathrm{kg}$, sampel 6 (kerang bakau) sebanyak 0,0170 mg/kg, sampel 7 (kerang bakau) sebanyak 0,0197 $\mathrm{mg} / \mathrm{kg}$, sampel 8 (kerang bakau) sebanyak 0,0151 mg/kg, sampel 9 (kerang bakau) sebanyak 0,0203 $\mathrm{mg} / \mathrm{kg}$, sampel 10 (kerang bakau) sebanyak 0,0163 $\mathrm{mg} / \mathrm{kg}$.

Berdasarkan Tabel 4 hasil output "independent sample test" pada bagian equal variances assumed diketahui nilai sig. (2-tailed) atau nilai $p=0.011<0.05$, maka sebagaimana dasar pengambilan keputusan dalam uji independent sample t test dapat disimpulkan bahwa $\mathrm{H} 0$ ditolak dan $\mathrm{H} 1$ diterima. Dengan demikian dapat disimpulkan bahwa ada perbedaan kadar timbal antara kerang darah dan kerang bakau.

\section{PEMBAHASAN}

Pada analisis kadar timbal $(\mathrm{Pb})$ dalam sampel kerang darah (Anadara granosa) dan kerang bakau (Telescopium telescopium) didapatkan dari tempat pelelangan ikan (TPI) Lappa Kabupaten Sinjai. Pada sampel 1,2,3,4,5 yaitu kerang darah (Anadara granosa) berasal dari Pesisir Pantai Angkue, Kecamatan Kajuara, Kabupaten Bone. Pada sampel 6,7,8,9,10 yaitu kerang bakau (Telescopium telescopium) berasal dari Hutan Bakau Bakkoe, Kecamatan Salomekko, Kabupaten Bone.

Dalam pelaksanaannya, sampel yang dianalisis dengan instrument SSA harus berwujud cair. Oleh karena itu, sampel kerang sebelumnya harus didestruksi terlebih dahulu dengan menggunakan $\mathrm{HNO}_{3}$ pekat sambil dipanaskan. Proses destruksi ini bertujuan untuk mempersiapkan sampel kerang agar dapat dianalisis (berwujud cair) dengan menggunakan destruksi kering. Tujuan penggunaan $\mathrm{HNO}_{3}$ pekat adalah untuk melarutkan serbuk kerang serta untuk menghilangkan senyawa organik yang ada pada kerang sehingga benar-benar diperoleh kandungan timbal $(\mathrm{Pb})$ yang terukur dalam sampel kerang dan untuk melarutkan atau melarutkan logam logam yang terdapat dalam sampel karena asam Nitrat dapat menstabilkan logam-logam yang akan dianalisis.

Selain itu, dalam proses destruksi juga dilakukan dengan pemanasan menggunakan penangas listrik. Pemanasan 
berfungsi untuk membantu mempercepat proses pelarutan atau pemutusan ikatanikatan organik. Setelah itu sampel diencerkankan dan hasil pengenceran tersebut kemudian dianalisis (Fitriani, 2012) serta untuk mempercepat dan menyempurnakan proses destruksi. Setelah semua serbuk kerang larut dan diperoleh larutan yang bening, kemudian larutan diencerkan. Sampel yang telah diencerkan kemudian disaring dan diukur dengan menggunakan alat SSA. Pengukuran absorbansi larutan seri baku standar timbal $(\mathrm{Pb})$ pada panjang gelombang $217 \mathrm{~nm}$. Setelah diketahui absorbansi dari larutan seri baku standar, kemudian dibuat kurva kalibrasi, sehingga dapat diperoleh nilai persamaan regresi linier $y=0.0098 x$ 0.0007.

Hasil penelitian menunjukkan bahwa dari 10 sampel kerang yang diteliti semuanya positif mengandung logam berat timbal $(\mathrm{Pb})$. Logam timbal $(\mathrm{Pb})$ pada kerang disebabkan oleh cemaran lingkungan diudara yang secara tidak sengaja masuk kedalam kerang dan tidak dapat dihindari yang berasal dari berbagai aktivitas manusia yang kemungkinan besar masuk kedalam perairan dan dapat tercemar timbal seperti diantaranya bahan bakar bensin yang beradiktif dan lalu lintas kapal nelayan.

Berdasarkan persamaan regersi linier maka diperoleh hasil kadar timbal $(\mathrm{Pb})$ pada kerang darah (Anadara granosa) dengan rata-rata $0,0439 \mathrm{mg} / \mathrm{kg}$ sedangkan pada kerang bakau (Telescopium telescopium) dengan rata-rata $0,0176 \mathrm{mg} / \mathrm{kg}$, tetapi tidak melebihi ambang batas maksimum yang ditetapkan oleh Standarisai Nasional Indonesia (SNI) tahun 2009 yaitu sebesar $1,5 \mathrm{mg} / \mathrm{kg}$. Absorbsi logam berat oleh suatu biota membutuhkan waktu yang relatif lama. Menurut Wardani et al. (2014), proses pengendapan terutama logam-logam berat yang tersebar di perairan akan terakumulasi dalam sedimen kemudian terakumulasi pada biota yang ada di dalam perairan.

Meskipun hasil yang diperoleh tidak melebihi ambang batas maksimum yang ditetapkan oleh Standarisai Nasional Indonesia (SNI) tahun 2009, namun bukan berarti bahwa kerang dari daerah tersebut aman untuk dikonsumsi, apalagi jika mengkonsumsinya dikatakan hampir setiap hari. Hal ini disebabkan karena logam berat timbal $(\mathrm{Pb})$ bersifat akumulatif dalam tubuh manusia sehingga keracunan akut dalam waktu dini belum dapat terdekteksi tetapi lama-kelamaan akan menghasilkan keracunan yang kronis yang pada akhirnya menyebabkan suatu penyakit yang menyerang saraf pusat apabila konsentrasi logam berat timbal $(\mathrm{Pb})$ tersebut di dalam tubuh manusia sudah tidak dapat ditoleransi oleh tubuh manusia itu sendiri.

Dampak logam timbal (Pb) pada kesehatan yaitu hipertensi, gangguan saraf, nyeri otot dan sendi, mati rasa atau kesemutan dikaki dan tangan, sulit tidur, nyeri perut dan kram, muntah, kejang, sulit berkonsentrasi atau mengingat sesuatu, sakit kepala, kehilangan kemampuan mendengar, merasa gelisah, penurunan atau gangguan produksi sperma (Apriyanti, 2018).

Penelitian sebelumnya juga dilakukan oleh Naimin (2014) dengan judul penelitian tentang "Analisis kadar timbal $(\mathrm{Pb})$ pada kerang darah (Anadara granosa) di perairan teluk bone (Kab. Sinjai) dengan menggunakan metode Spektrofotometer Serapan Atom" mendapatkan hasil bahwa kandungan logam timbal $(\mathrm{Pb})$ yang terkandung dalam kerang darah (Anadara granosa) sampel I sebesar $0,0739 \mathrm{mg} / \mathrm{kg}$ dan sampel II sebesar $0,0267 \mathrm{mg} / \mathrm{kg}$, berarti tidak melebihi juga ambang batas maksimum menurut Standar Nasional Indonesia (SNI) tahun 2009 yaitu sebesar $1,5 \mathrm{mg} / \mathrm{kg}$.

Berdasarkan table hasil output SPSS untuk uji "independent sample t-test" pada bagian equal variances assumed diketahui nilai sig. (2-tailed) sebesar $p=0.011<0.05$, maka sesuai dengan dasar pengambilan keputusan dalam uji independent sample $t$ test bahwa $\mathrm{H} 0$ ditolak dan $\mathrm{H} 1$ diterima. Dengan demikian dapat disimpulkan bahwa terdapat perbedaan yang signifikan antara kadar timbal dalam kerang darah dan kerang bakau.

Adanya perbedaan kadar timbal $(\mathrm{Pb})$ antara kedua sampel kerang dapat disebabkan karena faktor lingkungan dan habitat masing-masing kerang. Kerang darah (Anadara granosa) hidup dibagian pesisir pantai dan merendam di dalam pasir yang berlumpur, dimana sedimen dengan kandungan lumpur (debu) yang tinggi akan meningkatkan akumulasi logam. Kondisi sedimen dengan fraksi lumpur akan berpengaruh terhadap konsentrasi logam (Hamzah dan Setiawan, 2010).

Sedangkan kerang bakau (Telescopium telescopium) hidup di daerah terumbu karang dan banyak di dapatkan di 
hutan mangrove serta mampu hidup di perairan bakau tropis. Mangrove dinilai dapat menyerap logam berat melalui akarnya, sehingga menyebabkan nilai kontaminasi $\mathrm{Pb}$ pada air laut ini teridentifikasi lebih rendah. Menurut Purwiyanto (2013), selain menyerap logam pada sedimen, akar-akar mangrove tersebut juga dapat menyerap logam yang terdapat pada kolom air, mengingat akar kedua jenis mangrove dapat terendam air pada saat air pasang.

\section{KESIMPULAN}

Berdasarkan hasil penelitian yang diperoleh maka dapat disimpulkan bahwa:

1. Sejumlah 10 sampel diperoleh hasil masing-masing untuk sampel kerang darah yaitu $0,0500 \mathrm{mg} / \mathrm{kg}, \quad 0,0185$ $\mathrm{mg} / \mathrm{kg}, 0,363 \mathrm{mg} / \mathrm{kg}, 0,0493 \mathrm{mg} / \mathrm{kg}$, dan $0,0654 \mathrm{mg} / \mathrm{kg}$, sedangkan pada masingmasing sampel kerang bakau yaitu $0,0170 \mathrm{mg} / \mathrm{kg}, 0,0197 \mathrm{mg} / \mathrm{kg}, 0,0151$ $\mathrm{mg} / \mathrm{kg}, \quad 0,0203 \mathrm{mg} / \mathrm{kg}$, dan 0,0163 $\mathrm{mg} / \mathrm{kg}$.

2. Analisis data dengan menggunakan uji independent sampel T- test diperoleh bahwa terdapat perbedaan kadar logam timbal $(\mathrm{Pb})$ pada kerang darah (Anadara granosa) dan kerang bakau (Telescopium telescopium) dengan nilai $\mathrm{p}=0.011<0.05$.

\section{SARAN}

Berdasarkan hasil penelitian yang telah dilakukan, maka saran yang dapat disampaikan, yaitu:

1. Kepada masyarakat untuk lebih memperhatikan bahaya logam berat yang terkandung didalam kerang dan tidak mengkonsumsi kerang secara terus-menerus.

2. Perlunya dilakukan penelitian tentang keberadaan logam berat lainnya pada berbagai jenis kerang yang diperjualbelikan di tempat pelelangan ikan (TPI) Lappa Kabupaten Sinjai.

\section{UCAPAN TERIMA KASIH}

Penulis ucapkan terima kasih kepada Direktur dan Ketua LPPM Politeknik Kesehatan Muhammadiyah Makassar, ketua program Studi D3 Teknologi Laboratorium Medis yang telah memberikan permohonan izin penelitian serta seluruh staf Balai Besar Laboratorium Kesehatan Makassar khususnya Laboratorium Kimia Kesehatan yang membantu dalam pengujian sampel selama penelitian.

\section{DAFTAR PUSTAKA}

Amin, B., Evy, A., Mikel, A.S. 2011. Distribusi Spasial Logam Pb Dan $\mathrm{Cu}$ Pada Sedimen Dan Air Laut Permukaan Di Perairan Tanjung Buton Kabupaten Siak Provinsi Riau. Jurnal Teknobiologi, II (1): 1-8.

Aprianti, E. 2018. Analisis kandungan logam berat Timbal $\mathrm{Pb}$ pada Kerang Polymesoda erosa $L$ di Perairan Tanjung Bunga Makassar. International Journal of Educational and Environmental Education (IJEEM). ISSN: 2597.8020. 3 (2): 121 $-131$.

Emmawati, E., Aprianto, R., Musfiroh, I., 2015. Analisis Timbal Dalam Kerang Hijau, Kerang Bulu, Dan Sedimen Di Teluk Jakarta. Intonesian Journal of Pharmaceutical Science and Technology. 2 (3): 105 - 111.

Fitriani 2012. Penentuan Kadar Kalium (K) dan Kalsium (Ca) dalam Labu Siam (Sechium edule) Serta Pengaruh Tempat Tumbuhnya. Jurnal Akademika Kimia, 1(4), 174-180.

Hamzah, F dan Setiawan, A. 2010. Akumulasi Logam Berat $\mathrm{Pb}, \mathrm{Cu}$, dan Zn, di Hutan Mangrove Muara Angke, Jakarta Utara. Jurnal IImu dan Teknologi Kelautan Tropis. 2 (2): 41 51

Melinda, M., Sari, S.P., dan Rosalina, D. 2015. Kebiasaan Makan Kerang Kepah (Polymesoda erosa) di Kawasan Mangrove Pantai Pasir Padi. Oseatek, 9(1): 35-44.

Naimin, N. 2014. Analisis Kadar Timbal (Pb) pada Kerang Darah (Anadara granosa) di Perairan Teluk Bone (Kab. Sinjai) dengan menggunakan Metode Spektrofotometer Serapan Atom. Skripsi Fakultas IImu Kesehatan. UIN Alauddin Makassar. 
Purwiyanto, S. I. 2013. Daya serap akar dan daun mangrove terhadap logam tembaga $(\mathrm{Cu})$ di Tanjung Api-Api, Sumatera Selatan. Maspari Journal. 5(1): 1-5.

Rachmawati, R., \& Ma'ruf, W. F. (2013). Pengaruh lama perebusan kerang darah (Anadara granosa) dengan arang aktif terhadap pengurangan kadar logam kadmium dan kadar logam timbal. Jurnal Pengolahan dan Bioteknologi Hasil Perikanan, 2(3), 41-50.

Setiawan, H. 2013. Akumulasi Dan Distribusi Logam Berat Pada Vegetasi Mangrove Di Perairan Pesisir Sulawesi Selatan. Jurnal IImu Kehutanan, 8(1): 12-24.

Standar Nasional Indonesia, 2009. Batas Maksimum cemaran Logam Berat dalam pangan, Badan Standar Nasional, Jakarta.

Standar Nasional Indonesia, 2004. Cara uji timbal $(\mathrm{Pb})$ dengan Spektrofotometer Serapan Atom (SSA)-nyala.
Stang. 2014. Cara Praktis: Penentuan Uji Statistik dalam Penelitian Kesehatan dan Kedokteran. Jakarta: Mitra Wacana Media. Pp: 1 11.

Ramadhan M. F., Syafruddin N., Efriyeldi. 2017. Karakteristik Habitat dan Populasi Kerang Bambu (Solen lamarckii) di Zona Intertidal Desa Teluk Lancar Kecamatan Bantan Kabupaten Bengkalis. Jurnal Perikanan dan Kelautan. 22 (1): 3643

Syah, E. 2017. Analisis Kualitas Air Lindian Slag Ferronikel Pt. Aneka Tambang Tbk. Ubpn Sultra. Program Studi Teknik Pertambangan Fakultas IImu dan Teknologi Kebumian. Universitas Halu Oleo. Kendari.

Wardani, K. A., Dewi, K. N., Utami. R. N. Akumulasi logam berat timbale $(\mathrm{Pb})$ pada daging kerang hijau (Perna viridis) di Muara Sungai Banjir Kanal Barat Semarang. Unnes Journal of Life Science. 3(1): 1-8. 
Tabel 1. Hasil Absorbansi Larutan Baku Standar Timbal

\begin{tabular}{ccc}
\hline No. & Konsentrasi $(\boldsymbol{\mu g} / \mathbf{L})$ & Absorbansi \\
\hline 1 & 10 & 0,0915 \\
2 & 20 & 0,2069 \\
3 & 30 & 0,2807 \\
4 & 40 & 0,3948 \\
5 & 50 & 0,4887 \\
\hline
\end{tabular}

(sumber: data primer, 2019)

Tabel 2. Hasil Absorbansi dan Konsentrasi Sampel

\begin{tabular}{cccc}
\hline NO & Kode Sampel & Absorbansi & Konsentrasi $(\boldsymbol{\mu g} / \mathbf{L})$ \\
\hline 1 & Kerang Darah 1 & 0,0989 & 10,1824 \\
2 & Kerang Darah 2 & 0,0357 & 3,7225 \\
3 & Kerang Darah 3 & 0,0712 & 7,3511 \\
4 & Kerang Darah 4 & 0,0975 & 10,0393 \\
5 & Kerang Darah 5 & 0,1296 & 13,3204 \\
6 & Kerang Bakau 1 & 0,0332 & 3,4670 \\
7 & Kerang Bakau 2 & 0,0386 & 4,0189 \\
8 & Kerang Bakau 3 & 0,0290 & 3,0377 \\
9 & Kerang Bakau 4 & 0,0394 & 4,1007 \\
10 & Kerang Bakau 5 & 0,0314 & 3,2830 \\
\hline
\end{tabular}

(sumber: data primer, 2019)

Tabel 3. Hasil Uji Kuantitatif Kadar Timbal (Pb)

\begin{tabular}{cccc}
\hline No & Kode Sampel & $\begin{array}{c}\text { Kadar Timbal (Pb) } \\
\mathbf{~ m g / k g}\end{array}$ & $\begin{array}{c}\text { Rata } \mathbf{~ R a t a} \\
\mathbf{~ m g / k g}\end{array}$ \\
\hline 1 & Kerang Darah 1 & 0,0500 & \\
2 & Kerang Darah 2 & 0,0185 & \\
3 & Kerang Darah 3 & 0,0363 & 0,0439 \\
4 & Kerang Darah 4 & 0,0493 & \\
5 & Kerang Darah 5 & 0,0654 & \\
6 & Kerang Bakau 1 & 0,0170 & 0,0176 \\
7 & Kerang Bakau 2 & 0,0197 & \\
8 & Kerang Bakau 3 & 0,0151 & \\
9 & Kerang Bakau 4 & 0,0203 & \\
10 & Kerang Bakau 5 & 0,0163 & \\
\hline (sumber: data primer, 2019) & &
\end{tabular}


Tabel 4. Uji Independent T-Test

Independent Samples Test

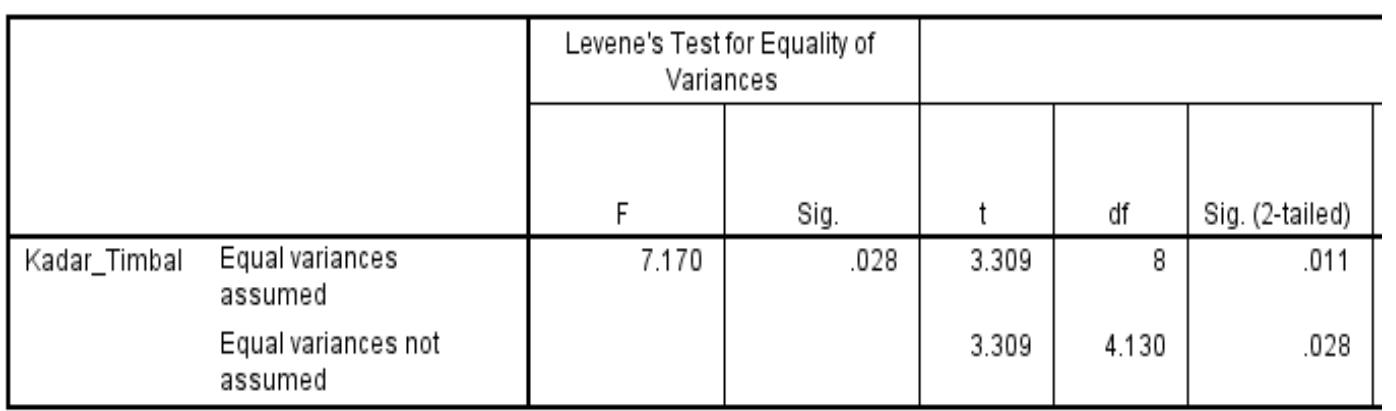

Tabel 5. Perhitungan Regresi Linear Larutan Standar Timbal (Pb)

\begin{tabular}{|c|c|c|c|c|c|}
\hline No. & $\mathbf{X}$ & $\mathbf{Y}$ & $\mathrm{X}^{2}$ & $\mathbf{Y}^{2}$ & $\mathbf{X . Y}$ \\
\hline 1 & 0 & 0.0006 & 0 & 0.00000036 & 0 \\
\hline 2 & 10 & 0.0915 & 100 & 0.00837225 & 0.915 \\
\hline 3 & 20 & 0.2069 & 400 & 0.04280761 & 4.138 \\
\hline 4 & 30 & 0.2807 & 900 & 0.07879249 & 8.421 \\
\hline 5 & 40 & 0.3948 & 1600 & 0.15586704 & 15.792 \\
\hline 6 & 50 & 0.4887 & 2500 & 0.23882769 & 24.435 \\
\hline$\sum 6$ & $\sum X 150$ & $\sum Y 1.4626$ & $\sum X^{2} 5500$ & $\sum Y^{2} 0.52466744$ & $\sum X . Y 53.701$ \\
\hline $\begin{array}{l}\text { Rata- } \\
\text { rata }\end{array}$ & $=25$ & $=0,2437$ & $=916,666$ & $=0,0874445733$ & $=8,95016667$ \\
\hline
\end{tabular}




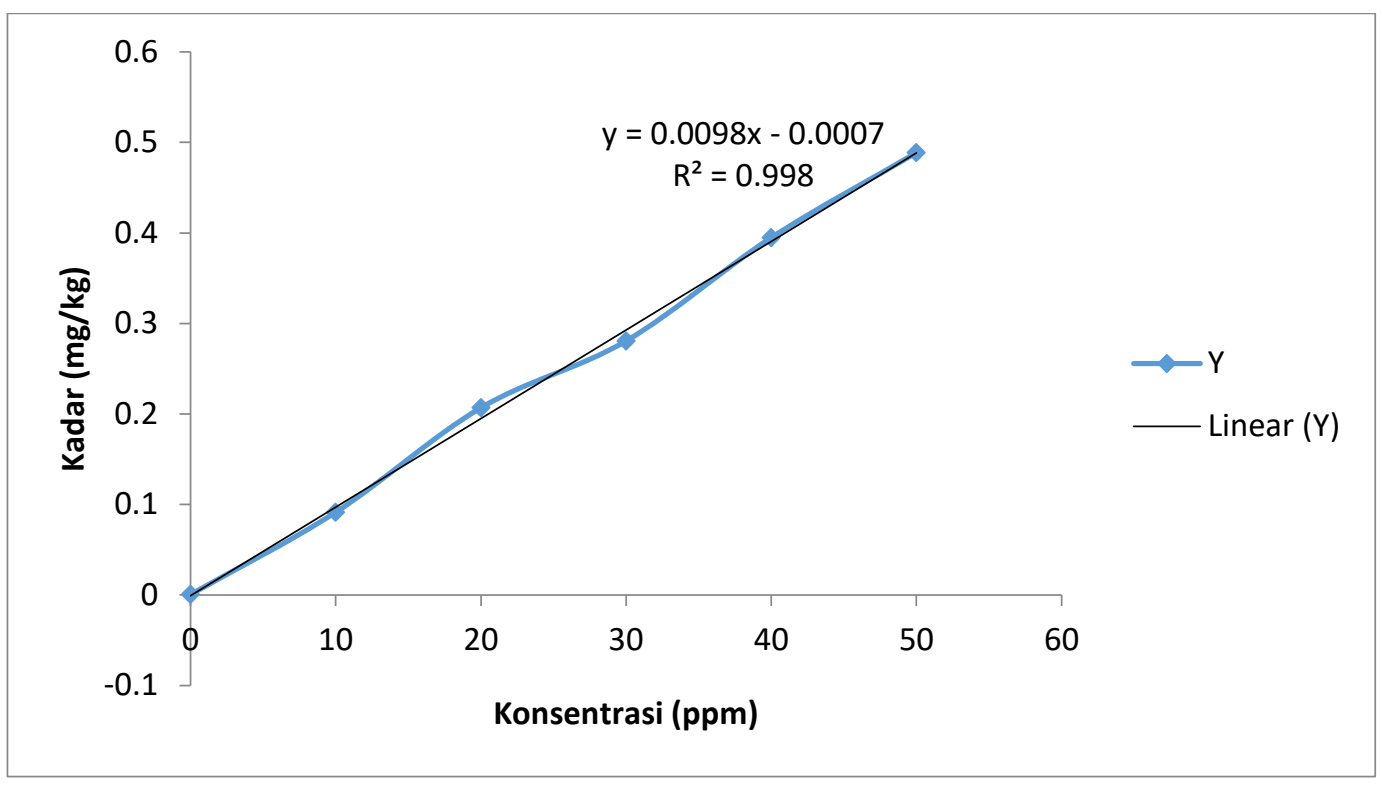

Gambar 1. Grafik Persamaan Regresi Linear Larutan Standar 